\title{
The Emergence of Public Spheres in Colonial Cameroon: The Case of Palm Wine Drinking Joints as lieux de sociabilité in Bamenda Township
}

\author{
Nicodemus Fru Awasom*
}

\begin{abstract}
Although Habermas might not have had Africa in mind when he propounded his public sphere theory, we still find his basic premise useful in capturing the public sphere scenario in Africa where people like to periodically congregate in various sites to socialize and indulge in political discourse while drinking. Using the case of colonial Bamenda township, this study examines the emergence and functioning of palm wine drinking joints as public spaces par excellence. These palm wine joints were comparable to European coffee shops and salons which were areas where various people could gather and discuss matters that concerned them. The palm wine joints were informal public spaces that emerged to respond to urbanization and cosmopolitanism, and stood out as one of the distinctive lieux de sociabilité. They were accessible to people of all classes and served as centres for drinking traditional liquor, gathering and spreading news and rumours, discussing politics and social issues, playing and dancing the 'bottle dance', and transiting to the 'red streets' to visit damsels after sucking in alcohol. The study relied on interviews and archival material as data for this article.
\end{abstract}

\section{Résumé}

Bien que Habermas n'avait surement pas en tête l'Afrique lorsqu'il avançait sa théorie de la sphère publique, nous trouvons toujours son hypothèse de base utile pour reproduire le scénario de la sphère publique africaine où les gens aiment se rassembler périodiquement dans différents sites pour socialiser et s'adonner au discours politique tout en buvant. Prenant le cas de la commune coloniale de Bamenda, l'étude

* University of Swaziland, Kwaluseni, Swaziland.Email: awasomnf@yahoo.com 
examine l'émergence et le fonctionnement des bistrots à vin de palme comme des espaces publics par excellence. Ces bistrots à vin de palme étaient comparables aux boutiques et salons de café européens qui étaient des endroits où diverses personnes pouvaient se rassembler et discuter des questions qui les concernaient. Les bistrots à vin de palme étaient des espaces publics informels qui ont émergé pour répondre à l'urbanisation et au cosmopolitisme, et se sont distingués comme étant l'un des Lieux de sociabilité par excellence. Ils étaient accessibles aux personnes de toutes classes et ont servi de centres de consommation de boissons alcoolisées traditionnelles, de collecte et de diffusion de nouvelles et de rumeurs, de discussion sur des questions politiques et sociales, de jeux et de « danse de la bouteille », et de transit vers les « rues rouges » pour rendre visite aux demoiselles après avoir bu l'alcool. L'étude s'est fondée sur des entrevues et des documents d'archives comme base de données de cet article.

\section{Introduction}

Most contemporary conceptualizations of the public sphere are based on the ideas expressed in Jürgen Habermas's book, The Structural Transformation of the Public Sphere - An Inquiry into a Category of Bourgeois Society. Although Habermas's concept of public space has been subjected to multiple criticisms, reviews and interpretations by other scholars (cf. Hohendahl 2001; Freundlieb, Hudson and Rundell 2004) this author still finds his basic premise useful in capturing the public sphere scenario in Africa, represented by the periodic congregation of people in various sites to socialize and indulge in discourses, not necessarily orderly discourses, but any interaction whereby the interested public engages each other while relaxing in various ways including drinking, playing cards, eating or dancing.

Habermas's concept of the public sphere encompasses a variety of meanings, including social sites or arenas where meanings are articulated, distributed, and negotiated, as well as the collective body constituted by, and in this process, 'the public'. Thus, any area in social life where people congregate and freely discuss and identify societal problems and, through that discussion influence political action, constitutes the public sphere.

In the public sphere, social and political discussion and participation are enacted through the medium of talking, debating, entertainment and relaxation. From this complex web of interactions, public opinion is formed and refined in an informal way. Conceptually, the public sphere is distinct from the state because activities in the public sphere include the production and circulation of discourses that can be critical of the state. It is a counter-public to the state. The basic belief in public sphere theory is that political action is steered 
by the public sphere, and that the only legitimate governments are those that listen to the public sphere as an alternative voice. President Ahmadou Ahidjo's one-party state in Cameroon was very sensitive to public opinion, and critical political statements emanating from the public sphere in the shape of bars and 'chicken parlours' were often monitored by the secret police and their authors sometimes paid dearly for them. The Ahidjo government viewed the public sphere as the thermometer of societal thinking as well as centres of subversion which had to be monitored by the state security apparatus.

This paper sets out to examine the emergence and functioning of palm wine drinking joints in twentieth century colonial Bamenda Township as public spheres par excellence à la Habermas. These palm wine joints were comparable to the Banta Bas or open spaces under baobab trees in The Gambia where men congregate on a daily basis to discuss and debate for hours and drink tea. Other comparable public spheres are European coffee shops and salons which were areas where various people gathered and discussed matters that concerned them. The public sphere was well established in various locations, including coffee shops and salons, areas of society where various people could gather and discuss matters that concerned them. The coffee houses in London were centres of art and literary criticism, which gradually widened to include even economic and political disputes as matters of discussion. Palm wine drinking joints in Bamenda Township, and Gambian Banta Bas, fall in this same category of public spheres and they also served as places of artistic creation, public opinion moulds, dangerous opposition politics, gossips, sinful behaviour or moral degeneration.

It is argued that the palm wine drinking joints represented public 'spaces and arenas' - together with the structures, processes, social actors and actresses and cultures associated with or built into them. The joints stood out as a distinctive lieu de sociabilité in Bamenda Township, specialized in the sale of native liquor, particularly palm wine, during the day and at nightfall with the weekends as the peak periods. As a public sphere, the palm wine drinking joints developed and functioned as regular meeting and discursive places for men and women; and such places became news and rumour generating machine, and a mandatory passage for men heading for the brothels. The palm wine drinking joints were also public spaces for the appropriation and reproduction of modernity through the bottle dance, an alternative form of high life music, and the centre for the discussion of the politics of independence.

This paper is divided into four parts. The first part provides a background and deals with theoretical issues related to Jürgen Habermas's public sphere concept and its applicability to the African context, with reference to Bamenda 
Township. The second part looks at the historical context of the development of palm wine joints as public spheres and discusses how these joints functioned in terms of the sociability of the actors and actresses. The third part examines how the public sphere served as sites for the appropriation and reproduction of modernity and political discourses. The problem of the governance of the palm wine joint is examined. The last part is the conclusion.

Writing this paper was partly facilitated by the fact that the author lived the dynamics of palm wine joints in Bamenda Township. He therefore made a collection of stories from his drinking mates. He also relied on interviews he had collected during research in the area in the 1980s. As a historian, resort was made to the archives for some salient information. This paper is therefore an introduction to the wider theme of public spheres as lieux de sociabilité dans la longue durée.

\section{Conceptualising and Contextualising the Public Sphere}

The public sphere refers to areas in social life where people congregate and freely discuss and identify societal problems and, through such discussion, influence public opinion and, inadvertently, politics. It is the sphere of private people who come together to constitute a public and engage in debates over general issues in the basically privatised but publicly relevant sphere of commodity exchange and social labour. The public sphere is therefore a discursive space where private individuals or groups meet to relax and discuss matters of mutual interest and where possible, to reach a common judgement, which may be encomiums for, or a mild or scathing critique of, a political regime. It is in such physical spaces that political participation is enacted through the medium of talk and where public opinion is moulded (Benhabib 1992; Warner 1992).

The 'public sphere' mediates between the 'private sphere' or ordinary citizens (or the civil society in the narrower sense) and the 'sphere of public authority'. Whereas the sphere of public authority represents the state or the realm of the ruling class and the state security apparatus including soldiers, gendarmes and police, the public sphere crosses over both these realms and, through the instrument of public opinion, the state is sensitised to the concerns of its citizenry.

The public sphere is conceptually distinct from the state in that it is the site for the production and circulation of discourses that can be critical of or hostile to the state and may not be seen as an arm of the state. It is also different from the official economy in that it is not an arena of market relations but rather one of discursive relations, 'a theatre for debating and deliberating rather than for buying and selling'. These fine distinctions between 'state apparatuses, economic markets, and democratic discussions' are essential 
to democratic theory and governance. The public sphere is a regulatory institution against the authority of the state.

The study of the public sphere therefore hinges on participatory democracy from the angle of the influence of public opinion on government policy or how public opinion influences or regulates government action. The basic contention of the public sphere theory is that political action is influenced by the public sphere and the only legitimate governments are those who are sensitive to public opinion (Warner 1992, 2002). Experiences from the African political scene might not comply fittingly with the concept of political legitimacy and sensitivity to public opinion. Rather, the political sensitivity of African governments is to issues which might provoke their ouster, and that is where its importance lies.

Public sphere theory is admirably captured in Haine's (1996) The World of the Paris Cafe: Sociability among the French Working Class, 1789-1914. The Paris cafes, like palm wine drinking joints, were privately owned places open to the public for relaxation and they fall into the category of public spheres. The cafes had a remarkable presence in the political, social, cultural, and intellectual life of eighteenth and nineteenth century Paris. In French cafes, people freely expressed their opinions and any new work, or a book or a musical composition had to be endorsed in these places by its public to get its legitimacy. Such public spheres not only created a forum for selfexpression, but in fact had become a platform for airing opinions and agendas for public discussion and endorsement. Cafes therefore stood as informal institutions that 'bridged the distance between public and private life, leisure and work, the individual and the family'. They also 'provided a unique space in which the tensions arising from such juxtapositions could be articulated' (Haine 1996:236).

The Paris cafes were important public spheres in French history owing to their importance as incubators of the revolutions of the eighteenth and nineteenth centuries that killed and buried the monarchy for good. At secondary and high school, we used to be taught how the ideas of the philosophers, which contributed to the overthrow of the ancien régime, circulated in the Paris cafes. Haine treats the role of the cafe in the revolutionary eruptions of 1789-1794, 1830, 1848 and 1870-1871 and argues that cafe sociability helped to create and spread new ideas during periods of free expression. During the times of repression following these revolutions, cafes served as shelters and as places where the working classes could express themselves by insulting government officials and the police.

The palm wine leisure joints in Bamenda Township in Cameroon stood out as an equivalent of French cafes in some respects with an equally interesting historical role in impacting on public opinion and the political orientation of 
Cameroon's path to independence. Palm wine is a multi-purpose socialization liquor, which Cameroonians, like other West and Central Africans who own palm trees, enjoy drinking, particularly during the evenings, and is used for libation, bride price and soothsaying, among other things. Palm wine drinking joints therefore bring people together. Tradition requires that all notables must sit and drink palm wine with the Chief (King) of the village on special days as a sign of fidelity, homage and togetherness. ${ }^{1}$ In the Township, the typical village evening scene of togetherness and relaxation was recreated around palm wine joints, the only difference being that the clientele was cosmopolitan and the palm wine had to be paid for with money.

The palm wine leisure joint was a distinct African model of the public sphere in the sense that the class component of its constituents was not important. This model of the public sphere placed little premium on social differences or privileges. They were sites for the people of all backgrounds. This public sphere was therefore classless in the Nyererian sense of the word (see Nyerere 1967) unlike the Paris cafes. In a period when newspapers were near-absent and were only of limited elitist value, information dissemination and the formation of public opinion operated effectively within the medium of such palm wine houses during relaxation and entertainment moments. Even with the advent and popularisation of the radio, particularly in the postcolony, the palm wine joints remained effective news, information and opinion sites. These leisure joints represented 'spaces and arenas' together with the structures, processes, social actors and actresses and cultures associated with or built into them - that bear on the daily lives of the Township population, and which are of organic concern to them by virtue of their individual and collective membership of the urban community.

In the palm wine leisure joints, traditional liquor was the dominant form of alcohol for Africans during British colonial rule in the Cameroons. Although the consumption of palm wine was ubiquitous in West and Central African villages, its importance took another dimension when the tradition was transported and reproduced in the Townships ${ }^{2}$ for essentially commercial purposes. These palm wine joints came to mark a permanent aspect of an all-encompassing social life in Bamenda Township. The consumption of alcohol in these joints was not an end in itself but went beyond the attainment of happiness as painted by Willis. ${ }^{3}$

\section{Historical Context of the Development of the Public Sphere in Colonial Bamenda Township}

African Townships have exhibited different categories of public spheres as venues where people congregate frequently. ${ }^{4}$ When such places are accessible to all classes and the principal activity there is consuming alcohol and 
playing music, ${ }^{5}$ they become extremely important as focal points for leisure and entertainment.

The growth of Bamenda Township was also accompanied by the emergence and proliferation of public spheres including traditional bars where native palm wine was sold, on-license and off-licence bars where Europeanstyle bottled beer, grape wines and spirits were sold, and night clubs, mosques, churches and brothels. The palm wine joints stood out as one of the distinctive public spheres that developed in the Township and specialized over the years in the sale of native liquor, particularly palm wine, during the day and at nightfall.

Bamenda Township developed hand-in-hand with palm wine leisure joints as the town created an enabling environment for the location of such business venues. Bamenda is a crossroads town and all the inhabitants of Cameroon's North West Region have to pass through the town before getting to their various destinations. The town owes its origin to colonialism and inveterate Hausa traders. Following the German annexation of Cameroon in 1884 and its ultimate conquest and subjugation, Bamenda was selected as the German administrative headquarters for the entire Bamenda region, now the North West Province, and the German administration embarked upon building a Fort to serve as the German Governor's administrative offices (Awasom 2003).

The German presence created relative peace and security in Bamenda and the Hausa in Northern Nigeria, who are traditionally traders, took advantage of the propitious atmosphere to migrate to Bamenda, starting in 1903. They initially camped around the German Fort at the Bamenda up station before being displaced to the Mankon-Bamenda vicinity downtown. There, the Hausa created a new quarter, which they named Abakpa, and the place came to be known as Abakpa-Bamenda Township. The Hausa immigrants are therefore the real genesis of the Bamenda Township (Awasom 2003).

The Bamenda Township provided opportunities which attracted other ethnic groups into the area. The tax records in 1934 indicated over 5000 taxable males and a mixed bag of ethnic groups comprising the indigenous Mankon, Bali, Bamum, Bamileke, Igbos, Fulani, Banso, Meta and a host of isolated ones. ${ }^{6}$ Essentially, the increasing population of Bamenda was fast becoming heterogeneous. Like other townships in Africa, Bamenda was a place for business and highlife, and the palm wine joints were a major spot of attraction and festivity after a hard day's work.

The palm wine leisure joints developed in Bamenda Township from the private initiative of women who followed the emerging town to cater for the needs of its cosmopolitan population. Mama Ngum is credited to have commenced the first palm wine joint in a haphazard manner in the parlour of 
her sun-dried brick house. The success of her business paved the way for other women to enter the trade by building their own sun-dried brick houses to serve as palm wine joints. In the 1930s and 1940s, the palm wine joints were located exclusively at the north-eastern crossroads area of the Township. The joints were littered along the same street about some 200 metres east of the Hausa Abakpa quarters. ${ }^{7}$

Before the introduction and popularization of modern lager beer in Cameroon, local liquor, including palm wine ${ }^{8}$ and corn beer reigned supreme. Palm wine consumption at palm wine joints is what gave Bamenda Township an atmosphere of regular festivity, although of different tempos. As Madoeuf notes:

Indeed a town is viewed as the expression of the wish to be together, it is through the feast that this wish is confirmed. Also, the feast is the expression of what Michael Maffesoli calls 'social viscosity', this strange impulse that prompts people to attach themselves to each other (Madoeuf 2005:68).

Local liquor, including palm wine and corn beer, was responsible for pulling people to these lieux de sociabilite in the township. People tended to relax over calabashes of palm wine to kill the evening hours and tell old stories.

Corn beer was also sold at palm wine joints. It is manufactured from fermented corn from which two varieties are extracted. The first is called 'shah' and is whitish in colour. The second, called 'nkan', is brownish like Coca-Cola and is extracted from fried maize. The two varieties of corn beer have the capacity of getting somebody thoroughly drunk. Corn beer was also sold at palm wine joints to cater for the needs of certain customers who preferred it but the principal activity of the joints was the drinking of alcohol which opened the chapter to other social activities.

Mode of Relaxation, Gender and the Drinking Pattern in the Joints The palm wine drinking joints were rendezvous sites meant for entertainment and relaxation and were run exclusively by women. The explanation for the monopoly of the trade by women is that food also had to be provided in the palm wine joints to serve as a foundation before the commencement of drinking and women customarily cook for their families in Africa. Since food was an important complement to drinking, women tended to combine selling cooked food and palm wine. Men restricted themselves to transporting the palm wine to town and selling it to their female customers who took over the responsibility of retailing them in their respective joints. So, while men specialized as tappers and suppliers of palm wine, women tended to concentrate on selling the liquor. A social network was therefore established in the palm wine industry from the male producers and distributors to the 
female buyers and retailers. The interfaces between the rural palm wine sellers and the urban buyers were sites for a preliminary type of discourse and the dissemination of information.

The palm wine leisure joints were real rendezvous and socialization spots in Bamenda Township, the most populous town in colonial British Southern Cameroon. Although drinking palm wine was a daily evening activity of the people, weekends and pay time at the end of the month were the busiest moments at the joints. How was drinking generally organized by customers of palm wine leisure joints?

Drinking in the palm wine joints did not take place in a haphazard manner. Within the unique space of the palm wine drinking joints, the people developed a distinctive subculture with its own order, structure and rituals. The world of the public sphere, as Hauser (1999:69) notes, consists of cultural norms and common meanings from which interaction takes place. The people in palm wine joints followed a specific communal pattern of drinking that was dictated by African traditional etiquette in the villages. The calabash or bottle of palm wine that was purchased was poured into the cup of each member present in the joint, usually starting with the oldest or a title holder. Each member present in the joint took his turn to buy a round of palm wine when the one being consumed was exhausted. If an individual was broke, he could continue to drink for free in the belief that when his economic situation improved, he would also buy for others. Anybody who arrived in a palm wine joint and bought a bottle of palm wine had to serve his neighbour first as a way of starting a conversation. Although an individual could buy a bottle or gourd of palm wine liquor, the common rule was that he had to share with others who in turn would also buy for him and continue the sharing process. Generosity and sharing, and not individuality and selfishness, was the rule at palm wine leisure joints.

Each time a calabash of palm wine was emptied by the group, the dregs of the palm wine would be poured into the cup of the identifiable elders in the group as custom and tradition dictated. Men took the dregs in the belief that it augmented and improved their sperm content and sexual potency. The drinking cups were usually fabricated from the horn of a cow or dwarf cattle, and in only rare cases were modern drinking glasses used. Kola nuts often accompanied the drinking of palm wine and were bought and shared as a sign of solidarity.

There is a popular Cameroonian saying which states that the truth lies in the cup which means that when people booze, they tend to speak out their minds more freely without any restrictions. Drinking goes hand in hand with discussion. Hauser (1999:64, 69-70) notes that public spheres usually formed 
around certain issues that were deliberated on and the discussion would reproduce itself across a spectrum of interested publics who do not necessarily know each other and might be meeting each other for the first time. People would converse freely but with respect for their customs and tradition in mind with reference to age hierarchies and traditional titles. Such social differences were easily noticeable from the way an individual appeared and was dressed, the cap an individual wore and the way the cap was decorated. That notwithstanding, people in palm wine joints generally mixed freely and spoke their minds without any restrictions. No matter how heated debates became, fighting or assault was not culturally tolerated.

Palm wine leisure joints operated in the day and night. After doing business in the day, most people would pass through the palm wine joint and have a bottle of palm wine and cooked food. Daytime business was business as usual without much colour. Sometimes children could be seen assisting their mothers in selling.

Nightfall was usually a period of peer group gathering at the palm wine joints. Night business was another story because it was pretty busy and only adults were its main actors. The palm wine leisure joints were generally considered wayward milieus in the night because of the presence of men and a handful of lady sellers who mixed drinking with the use of obscene language. The near-decent women sellers would retort to men's obscene utterances in sexy innuendos while the shameless ones would call a spade a spade, or the penis the penis, to the pleasure and laughter of the men. The more embarrassing a woman was with her usage of sexy language, the more notorious she became and the more customers she would attract, who would come for a tease. Palm wine leisure joints were therefore places par excellence for the formulation of new sexual vocabularies. 'Decent' women therefore preferred to stay away from palm wine leisure joints after night fall for fear of being blacklisted as wayward.

The palm wine that was sold at nightfall was called 'over night'. It means it had been allowed to ferment for about two days and therefore had a high percentage of alcohol that would make heavy consumers drunk. Men preferred the fermented palm wine because of its high alcohol content, which would easily get them 'high' and in a mood for singing. Men who had business with the 'red lights street' preferred highly fermented palm wine.

\section{Palm Wine Leisure Joints as a Stop-over to Red Light Streets}

The palm wine leisure joints served as a stop-over to the red light streets in Bamenda Township, popularly known as Bayangi Quarters. The red light street was littered with brothels dominated by the Bayangi women from Cameroon's South West Region (Fomin 2004). Men would pass some time 
at the palm wine joint, drinking highly fermented palm wine, singing suggestive sexual songs and consuming 'traditional Viagra', composed of bitter kola nuts and special chewable roots. Bitter kola nuts used to be sold exclusively at palm wine leisure joints, the reason being that they were meant for sex. But the popularity of the bitter kola and its alleged medical potency in cleansing the body's system displaced the nuts from palm wine joints to market places.

When a man requested a package of traditional Viagra in an indiscreet manner while drinking palm wine, it usually provoked thunderous laughter for it was clear to all where such a man was heading to. After taking the traditional Viagra, it would be pushed down with some gulps of fermented palm wine in readiness for action. If a female artist or commercial sex worker smelled palm wine on a man' lips, the assumption was that the man must have taken traditional Viagra; consequently, such a customer would be expected to pay a higher fee since he would likely spend an unusually long period with the artist on the bed and would break her down. Some female artists deliberately refused to have anything to do with men who were suspected to have taken traditional Viagra because such men would substantially reduce the number of customers the artists would have had that night since Viagra consumers were alleged long rangers.

Women artists from the red streets sometimes went to the palm wine leisure joints to assist the female wine sellers for free in selling their commodities. The artists were often most welcomed since their presence, and sometimes their sexy dress styles, made the palm wine leisure joint attractive to customers. Women who were new arrivals also had an interest to go to the leisure joints in the evenings to advertise themselves and possibly catch a customer instead of just sitting indoors. Palm wine leisure joints were not only venues for drinking and meeting people but also places for music and politics.

\section{The Appropriation and Reproduction of Modernity and Political Discourses in the Joints}

Whereas coffee houses in London were centres of art and literary criticism, palm wine joints were also milieus for the appropriation and reproduction of modernity in the form of popular music. If there is anything for which the indigenous Mankon people of Bamenda Township are known, it is the bottle dance. Bottle dance stars such as John Menang, Richard Nguti, Ni Ken and Depipson (Nyamnjoh and Fokwang 2005:261) have been popularised by the Cameroon Radio Television (CRTV). What is hardly known is that this genre of music developed in palm wine drinking joints. Initially, the palm wine consumers would sing and dance their traditional music when they had taken 
much palm wine. ${ }^{9}$ With the spread of popular music in the form of high life, the urbanites quickly appropriated it and gave it a completely new twist.

The development of popular high life music in Cameroon dates back to colonial times and is closely related to urbanisation. Popular highlife music that was being played in Ghana and Nigeria ${ }^{10}$ reached the Cameroon urban centres, thanks to powerful radio transmitters and individuals from these centres of high life music (Nyamnjoh and Fokwang 2005:254). High life music was also played in a popular nightclub in Bamenda Township called Waterside Bar. But such nightclubs were elitist and exclusive.

In the palm wine leisure joints, the popular music played in modern bars was appropriated in another way by the people bent of demonstrating their up-to-date-ness with modernity. In the absence of guitars at the initial stages in the 1930s and 1940s, these modernists had to improvise music with bottles as the main instrument. Guitars were later acquired and were used alongside the bottles. The palm wine musicians sang a modified version of the popular music to communicate critical messages that caricatured the colonial elite, particularly their snobbishness and claims to superiority and their habits of monopolising all the beautiful women. With the introduction of political parties, hired bottle dance musicians often entertained people drinking by playing progovernment songs. The entertainer used a metal object to hit the bottle while another played the guitar and sang away. Then ladies and gentlemen would be invited to engage each other on the floor and they would dance according to the command of the lead singer. The bottle dance display on a grand scale was reserved for special weekends, special occasions and pay time. But during the week, isolated musicians would sing and play their guitars, accompanied by the bottle sounds just to please people in the leisure joints.

As the bottle dance grew in importance, it was displaced from the palm wine joints to the Township community hall on selected Saturdays reserved for the big dance for reasons of space. The women palm wine sellers would be organised on such occasions to supply wine to keep the occasion going. But the palm wine leisure joints remained the place for the production of bottle dance. Today, there are several Bamenda Township musicians who have specialised in playing a modernised version of the bottle dance whose origins can be traced to the palm wine joints.

Palm wine joints served as informal media centres in a society where newspapers were extremely difficult to come by until the early 1960 s. Frequenting the palm wine leisure joints was a regular practice of urbanites, not just for drinking but for the simple reason that they had to meet there to be informed about the latest socio-political events in town. There was always a story teller, a philosopher king, or a distinguished individual who would engage people in conversation on a variety of topics or simply entertain 
people with stories. Keeping away from palm wine joints meant missing a lot in town and appearing really backward. The best source of information on the latest in town was therefore the version from the palm wine joints.

Politicians had to socialize with the people in the palm wine joints in the evenings. They would order and pay for rounds of palm wine to customers as a prelude to being given the floor to make political statements in favour of their political programmes.

Prince Ndefru, the President of the Township palm wine joints, grew in popularity as the people's arbitrator. He was therefore openly wooed by politicians with the formation of the first two political parties in the Southern Cameroons in 1953, the Kamerun National Congress (KNC) of E.M.L. Endeley and the Kamerun People's Party (KPP) of M.N. Mbile (ChemLanghee 2005).

During political campaigns preceding the United Nations plebiscites on the independence of the British Cameroons, which was contingent on joining either Nigeria or the French Cameroons, the various political protagonists used the palm wine joints to sell their programmes and discredit their rivals through rumours. The pro-Francophone Cameroon politicians spread rumours about the impending dangers of voting to join Nigeria by alleging that Igbo men were raping native women on a daily basis and compelling native people to buy their goods at exorbitant prices. Nigeria was presented as 'an ocean' that would drown the small British Cameroons in the case where it opted to join Nigeria while the aggressive Igbo traders would not give Cameroonians any breathing space in the economy. As for the proNigerian politicians, rumours were spread to exaggerate the state of civil war between the anti-French guerrillas and the Ahidjo government in a bid to scare people from voting to join the Francophone Cameroon Republic. Francophone Cameroon was presented as a chaotic and lawless society where civil liberties did not exist and where the gendarmes continuously terrorised the population. Palm wine joints therefore served as propaganda and rumourgenerating centres. Politicians hired bottle dance musicians to propagate their political manifestoes through their music. It was therefore a matter of paying the piper and calling the tune in palm wine joints.

\section{The Public Sphere and the Question of Governance}

As the palm wine joints grew in importance and popularity, the indiscipline and harassment arising from such places from the hands of hoodlums necessitated the establishment of a governance structure. The British colonial administration in the Cameroons was particularly thin on the ground, given that the Cameroons was more of an appendix of Nigeria and Britain was 
more concerned with its Nigerian colony than with the Trust territory of the Cameroons. The women palm wine sellers at the joints wanted the township administration under the British-appointed Hausa Chief, the Sarikin Hausawa, to be more active in the affairs of the palm wine joints. The Hausa Chief was reluctant to involve himself in palm wine matters because of his Muslim religion. The women quickly resorted to Prince Ndefru, a native of MankonBamenda Township, who was a big patron of the palm wine joints, to oversee their administration.

Ndefru accepted the presidency of the palm wine joints in the Township and all conflicts related to the operation of the joints were brought to him for arbitration. ${ }^{11}$ For instance, Prince Ndefru's council of arbitrators policed the palm wine joints, and handled cases of fighting or refusal to pay for drinks consumed. The local government, the Ngemba Native Authority, came to recognise Ndefru's role in the palm wine joints and with the colonial administration, they enlisted his services in collecting taxes therefrom. ${ }^{12}$ Although women were the principal proprietors of the joints, the organisational chart was composed exclusively of urban males under the leadership of Prince Ndefru. The Prince was popular among the palm wine women dealers given his imposing position as a native of Bamenda. Essentially, Prince Ndefru was catapulted to an enviable position of President of the palm wine joints in the Township because the British-appointed Hausa chief turned down the offer.

The emergence of Prince Ndefru as the President of the palm wine joints in the Township resulted in strained relations with the Hausa immigrant community. The Hausa community was uncomfortable with the activities of the palm wine joints because of political, religious and security reasons. The British-appointed Chief of the Township, the Sarkin Hausawa, complained bitterly to the British colonial administration that Prince Ndefru was undermining his authority by interfering in tax collection matters in the urban area. He complained that it was unacceptable for the palm wine joints to operate within the residential areas of the Hausa Muslims in the Township. Apart from dealing with alcohol which was offensive to Muslims, the palm wine joints were presented as unsafe places where hoodlums operated freely at night and gambling, fighting, prostitution were part of the palm wine business. The Sarikin Hausa requested the British to ban the sale of palm wine around Muslim Hausa quarters and to expel all women around the palm wine joints who were not involved in any visible gainful activity. ${ }^{13}$

The native peoples felt the Sarikin Hausawa had gone too far. Palm wine joints were their business in their native land and immigrants had no right to determine which business they should do. Moreover, palm wine was a cultural aspect of their lives. The British refused to displace the palm wine joints, 
which was the business of the native peoples and a source of taxable revenue for the local administration.

The conflict of authority between Prince Ndefru and the Sarikin Hausawa was resolved within the context of local government reforms. In 1949, the British initiated local government reforms which transformed the Native Authority system into a modern local government system. This reform package included the democratisation of local governments to allow the inclusion of educated elements, and the representatives of various ethnic and interest groups, including women, in the Township. The reforms culminated into the establishment of a new local government known as the Mankon Subordinate Native Authority Council or the Mankon Urban Council in 1954 as the governing body of the Township. ${ }^{14}$ The membership of the urban council was all-embracing and comprised the women palm wine sellers, Prince Ndefru, the Sarikin Hausawa and other representatives of interest groups in the Township.

The Councillors were divided into committees responsible for various domains including health, sanitation, education, finance, customary affairs and land issues. Women of the palm wine joints now had a voice under the local government reforms as their representatives could also sit in council. Perhaps the greatest victim of the reforms was the Sarikin Hausawa. His influence was considerably neutralized since the Hausa immigrants were a minority in the council and decisions had to be taken democratically and collegially. The dream of stamping out palm wine joints in Abakpa Bamenda Township died its natural death, as the Muslim minority could not take any decision against the majority indigenous and cosmopolitan non-Muslims of the Township.

\section{Conclusion and Epilogue}

This study set out to explore the emergence of the public sphere in colonial Bamenda Township. Dovetailing Habermas's theory of the public sphere which used European salons and cafes as discursive arenas, this study has revealed how the palm wine leisure joints in colonial Bamenda Township were equally public spheres par excellence where men and women regularly congregated. These public spheres were leisure joints performing multiple functions and were part and parcel of the urbanization process in twentieth century Cameroon.

The palm wine leisure joints as public spheres were accessible to everybody irrespective of class. Men drank palm wine and shared kola nuts at the palm wine leisure joints regularly as a normal way of life in the urban context, which was a reproduction of similar practices in the villages. But in town, the company at the palm wine joints was usually a mixed bag of ethnicities 
and native liquor in the joints had to be bought and was not on free offer as often happened in the countryside. These leisure joints were not only centres for drinking, but also for entertainment, news, rumours, politicking and dating, particularly artists of the red streets. The leisure joints were also places where high life music was transformed into bottle dance music which served not only for entertainment purposes but also as instruments of political propaganda and a critique of society. At the penultimate stage of the British Cameroon's independence, contingent on a merger with either Francophone Cameroon or Nigeria, palm wine joints became the centre stage of independence politics.

The palm wine joints actually gave the Township colour and vibration, and they soon developed governance structures to arbitrate and oversee their smooth functioning. The local government reforms that the British initiated in 1949 culminated in the integration of the governing structure of the palm wine leisure joints and the women palm wine dealers.

The palm wine joints as public spheres were subjected to changes in terms of location and importance in the postcolony. The leisure joints were initially located exclusively at the northeast crossroads area of the town and palm wines supplies came almost exclusively from the native Mankon people. The forces of change broke this monopoly. As Bamenda Township expanded, swallowing neighbouring towns like Nkwen and Mendakwe through the process of conurbation, the northeast crossroads leisure joint was challenged by the mushrooming of other rival joints, which continued to operate the same way.

The changing economic fortunes of Cameroon in the 1970s, reflected in the boom in the prices of agricultural exports and the advent of petrol, witnessed the popularization of beer drinking in bars, on-licenses and offlicenses ('les ventes emportés') by the emerging middle class. In other words, alternative public spheres emerged with a completely different culture that competed effectively with palm wine drinking joints.

Palm wine drinking joints, as public spheres, might not enjoy their old monopoly; but they have come to stay as permanent places in the Township with a special clientele who find fulfilment in them. The ordinary folk remain its first and faithful clientele and continue to give it colour by the old stories they tell of the yesteryears. If the ordinary folk cannot afford beer from the modern breweries, they can still get 'high' in the palm wine joints where they drink away the trials of a hectic day and tell the stories of old or make their own news. 


\section{Notes}

1. The British exiled Fai Ndzenzef, an important notable in colonial Nso in Cameroon's North West Province, partly because he had stopped drinking palm wine with the King of Nso in his palace and it was suspected he was up to making trouble and breaching the peace (cf. Awasom, Nicodemus Fru, 'The British Invention of Tradition and the Fai Ndzenzef Affair', Occasional Paper, University of The Gambia, 2006).

2. The town, as opposed to the countryside or rural environment, has its distinctive characteristics typified by its cosmopolitanism and the preponderance of secondary and tertiary activities. Towns in Africa have an old history and their growth is always related to the colonial presence, population movements and trade, among other factors (Cf. Hirsch and Fauvelle, 2004: 9-34)

3. Willis (p.265) states that the sole purpose of consuming alcohol by individuals was to achieve happiness. The brewing and consumption of alcohol is done in a bid to achieve this happiness.

4. Mosques, churches, and football stadiums, among others, are examples of such places that have been studied (cf. Cantome, Cleo, 'The contemporary mosque phenomenon as lieux de sociabilité: gender, identity and space', Fancello, Sandra, 'Du village au temple: les assemblée pentacôtiste comme espace de sociabilité en milieu urbain africain', Benjelid, Abed, 'Le stade de football: un formidable lieu de sociabilité et integration des jeunes de la périphérie pauvre de l'Oran, Algerie').

5. For interesting sidelines on drinking and music venues in urban centres in Africa see Fourchard, Laurent, Sheben, 'Sociabilité et pouvoir en Afrique du Sud au XXe siècle', Collins, John, 'A century of changing locations of Ghanaian commercial Popular Entertainment Venues'.

6. National Archives Buea, Cameroon, Annual Report for the year ending 31 December 1935.

7. Interviews with informant 1, Bayong, John, aged 55. Businessman and the son of a title holder from Mankon who told old stories about the palm wine joints of his traditional Mankon. Buea, Cameroon January 3-5, 2000; Informant 2, Awasom Stephen Anye, 75. Father of author and a stylish bottle dancer. His memory about palm wine joints were always fresh. Stories collected from him between 1980-1985 and 1998-2000 in Mankon-Bamenda; Informant 3, Pa Monikang, Alexander, 74 years. Native of Mankon and an excellent oral historian. A genuine lover of palm wine joints who tells his story in a musical fashion, particularly about the bottle dance and the red street queens Stories collected from him between 1980-1985 and 1998-2000; Informant 4, Ndenge, Alphonse, aged 78. Notable from Mankon and a retired educationist. Interviewed between 1980-1985 and during Summer holidays of 1999; Informant 5, Alhadji Usman, Bah, Hausa trader in Mankon town, son of the Sarikin Hausawa, aged 60. He was interviewed with six other Hausa people in February 1984 during collection of data for my Doctoral thesis for the University of Yaounde 1. 
8. Palm wine is extracted from palm trees, raffia palms and to a limited extent, dead palms. It is obtained by tapping sap from a variety of palm trees, which produce different types of palm wine.

9. Interview with informants 1-5.

10. For interesting sidelines on highlife music in Ghana see Collins, 'A century of changing locations of Ghanaian Commercial Popular Entertainment Venues'.

11. See Informants 1-512 Provincial Archives Bamenda/Cameroon, $\mathrm{Pa} / \mathrm{Bda} 10027$, 1949.

12. Provincial Archives Bamenda, Cameroon, $\mathrm{Pa} / \mathrm{Bda}$ 10027, 1949.

13. Nicodemus Fru Awasom, 'The Vicissitudes of twentieth-century Mankon Kings in Cameroon's Changing Social Order', in Wim van Binsbergen, ed., The Dynamics of Power and the Rule of Law, Leiden, African Studies Centre, 2003, pp.108-111.

14. Provincial Archives, Bamenda, File No. Ba/1934/b, Mankon Subordinate Native Authority.

\section{References}

Akyeampong, E., 1988, Drink, Power, and Cultural Change: A Social History of Alcohol in Ghana, c.1800 to Recent Times, Portsmouth, Oxford.

Awasom, N.F., 2003a, 'Hausa Traders, Residential Segregation and the Quest for Security in 20th Century Colonial Bamenda Township (Cameroon)', in Laurent Fourchard \& Issac Albert, eds., Security, Crime and Segregation in West African Cities Since the 19th Century, (Ifra/Karthala).

Awasom, N.F., 2003, 'The Vicissitudes of Twentieth-Century Mankon Kings in Cameroon's Changing Social Order', in Wim van Binsbergen, ed., The Dynamics of Power and the Rule of Law, Leiden: African Studies Centre.

Awasom, N.F., 2006, 'The British Invention of Tradition and the Fai Ndzenzef Affair', Occasional Paper, University of The Gambia .

Benhabib, S., 1992, Models of Public Space, Habermas and the Public Sphere, Cambridge Mass. : MIT Press.

Bryceson, D.F., 2002, ed., Alcohol in Africa: Mixing Business, Pleasure, and Politics, Portsmouth, N.H. : Heineman.

Benjelid, A., 2006, 'Le stade de football: un formidable lieu de sociabilité et integration des jeunes de la périphérie pauvre de l'Oran (Algerie)', Paper presented at Colloquium on «Les lieux de sociabilité urbaine dans la longue durée en Afrique (Afrique du Nord et Madagascar inclus) », Paris.

Cantome, C., 2006, 'The contemporary mosque phenomenon as lieux de sociabilité: gender, identity and space', Paper presented at Colloquium on « Les lieux de sociabilité urbaine dans la longue durée en Afrique (Afrique du Nord et Madagascar inclus) », Paris.

Collins, J., 2009, ‘A Century of Changing Locations of Ghanaian Commercial Popular Entertainment Venues', in Laurent Fourchard, Odile Goerg, MurielGomez-Perez, eds., Lieux de sociabilitei urbaine en Afrique, Paris: l'Harmattan. 
Fancello, S., 2008, « Du village au temple : les assemblées pentecôtistes comme espaces de sociabilité en milieu urbain africain », in Fourchard L., Goerg O. (éds.), Lieux de sociabilité en Afrique, Paris, L'Harmattan, Paper presented at Colloquium on «Les lieux de sociabilité urbaine dans la longue durée en Afrique (Afrique du Nord et Madagascar inclus) ».

Fomin, E.S.D., 2004, 'Understanding Banyang Women in Cameroon Urban Centres: Introspective and Perspectives', Occasional Paper of the Department of History, University of Yaounde 1.

Fourchard, L., 2006, 'Sheben, sociabilité et pouvoir en Afrique du Sud au XXe siècle', Paper presented at Colloquium on «Les lieux de sociabilité urbaine dans la longue durée en Afrique (Afrique du Nord et Madagascar inclus) », Paris.

Freundlieb, D., Hudson, W. and Rundell, J., eds., 2004, Critical Theory after Habermas: Encounters and Departures, Leiden, Boston : Brill.

Habermas, J., 1989, The Structural Transformation of the Public Sphere: An Inquiry into a Category of Bourgeois Society, Cambridge, Mass. : The MIT Press (trans.).

Hauser, G., 1999, Vernacular Voices: The Rhetoric of Publics and Public Spheres, Columbia : Columbia University of South Carolina Press.

Hirsch, B. and Fauvelle, F.X., 2004, 'Cités oubliées. Réflection sur l'histoire urbaines de L'Ethiopie médiévale (xie-Xvie siècle)', Journal des africanistes, tome 74: 299-331.

Hohendahl, P.U., 1982, “Critical Theory, Public Sphere, and Culture: Jürgen Habermas and His Critics." pp. 242-280 in The Institution of Criticism. Ithaca (NY)/London: Cornell University Press.

Holder, G., and Peatrik, 2004, 'Cité, centre capitale: pour une anthropologie du statut politique de la ville', Journal des africanistes, tome 74: 9-35.

Madoeuf, A., 2005, 'Feasts panoramas in town-spaces and times of the moulids of Cairo', in Abdou Simone \& Abdelghani Abouhani, eds., Urban Africa: Changing Contours of Survival in the City, Dakar: CODESRIA.

Nyamnjoh, F.B. and Fokwang, J., 2005, 'Entertaining Repression: Music and Politics in Postcolonial Cameroon ', African Affairs, 104/415: 251-274.

Nyerere, J.K., 1967, Socialism and Rural Development, Dar es Salaam : Government Printer.

Scott Haine, W. , 1996, The World of the Paris Cafe: Sociability among the French Working Class, 1789-1914, Baltimore, MD. , and London: Johns Hopkins University Press.

Warner, M., 1992, The Mass Public and the Mass Subject, Habermas and the Public Sphere, Cambridge , Mass. : MIT Press.

Warner, M., 2002, Publics and Counterpublics, New York: Zone Books.

Willis, J., 2002, Potent Brews: A Social History of Alcohol in East Africa, 18501999, Nairobi : British Institute in Eastern Africa/Athens: Ohio University Press / Oxford : James Currey. 


\section{Archival Sources}

National Archives Buea/Cameroon, Annual Report for the year ending 31 December 1935

Provincial Archives, Bamenda, File No. Ba/1934/b, Mankon Subordinate Native Authority

Provincial Archives Bamenda/Cameroon, Pa/Bda 10027, 1949

\section{Interviews}

Informant 1, John Bayong, aged 55. He is a businessman and the son of a title holder from Mankon who told him old stories about the palm wine joints of his traditional Mankon (interview with author on January 3- 5 in Buea/Cameroon, 2000).

Informant 2, Stephen Anye Awasom, 75. Father of author and a stylish bottle dancer. His memories of palm wine joints were always fresh. He tells the stories graphically, sings and dances away about palm wine joints which are losing the original significance (Stories collected from him between 1980 and 1985 and 1998-2000).

Informant 3, Pa Alexander Monikang, 74 years. Native of Mankon and an excellent oral historian. A genuine lover of palm wine joints who tells his story in a musical fashion, particularly about the bottle dance and the red street queens. (Stories collected from him between 1980 and 1985 and 1998-2000).

Informant 4, Alphonse Ndenge, aged 78. Notable from Mankon and a retired educationist. (Author interviewed him between 1980 and 1985 and during Summer holidays of 1999).

Informant 5, Alhadji Usman, Hausa trader in Mankon town, son of the Sarikin Hausawa, aged 60. He was interviewed with six other Hausa people in February 1984 during collection of data for my Doctoral thesis for the University of Yaounde 1. 